\title{
Covid-19: how Japan squandered its early jump on the pandemic
}

\author{
Japan's low covid-19 infection numbers were a wonder but led to a lapse in public vigilance. Now, \\ an explosion of cases has escalated measures that may be too little, too late, writes Erika Hayasaki
}

\author{
Erika Hayasaki journalism professor \\ University of California, Irvine, California, USA
}

On 15 April, more than a week after Japan declared a state of emergency, a steady stream of customers continued to show up to the Saito-yu Public Bath and Coin Laundry in the north east of Tokyo. The communal bathing facility, where patrons share saunas and hot tubs, remains open-albeit with hourly disinfections, shortened business hours, and no more serving of draft beer.

Public bath houses, or sentōs, have been deemed essential businesses by the government, along with grocery stores, pharmacies, and hospitals. Theatres, museums, and department stores have closed. Karaoke bars, pachinko game centres, internet cafes, and nightclubs have shut down temporarily. But restaurants and izakaya pubs remain open, albeit with hours limited to daytime. The Tokyo Metropolitan Government also failed in its bid to get barber shops, beauty parlours, and DIY stores to close their doors as part of the national government's official measures.

"Japan is not fully regulated. Many people are out in town," says Masahiro Kami, executive director of Japan's Medical Governance Research Institute, a non-profit group. "Many Japanese think that the mortality rate of covid-19 is low."

"People remain largely ignorant of the basic principle of "social distancing'-a term that remains unknown and alien in Japan," says Koichi Nakano, a dean and professor of political science at Sophia University in Tokyo.

"We have no idea about the scope of infection and the public cannot appropriately assess the risk of infection to date," Nakano told The BMJ, adding that "stay at home recommendations came too late."

\section{Self-restraint}

Japan's relaxed approach and slow response has been surprising, since the world's third largest economy hit the headlines early in the pandemic. Its first case was announced on 16 January, and February saw a spike in Hokkaido leading to a month long state of emergency for the northern prefecture, while infections also ramped up when the Diamond Princess cruise ship was quarantined for four weeks at Yokohama.
Japan is not enforcing social distancing rules, partly because by law it can't enforce closures or fine citizens for breaking the rules. Even under a state of emergency, now extended nationwide, ${ }^{1}$ there can be no mandatory lockdown as seen in other countries.

The Japanese government has instead politely appealed to people's voluntary "self-restraint" in avoiding spots that have poor ventilation, as well as crowded areas and settings where there may be close range conversations. These spots are being called the "three Cs."

They don't include packed rush hour trains or buses, with government advice giving the impression that the occasional opening of doors is sufficient ventilation. The confused list of which businesses are open and closed, along with the reluctance or unpreparedness of companies to facilitate remote working, make it seem like covid-19 only strikes at night.

For much of February and March, Japan's infection numbers remained low, even as other nations were sheltering in place for weeks. And although schools nationwide closed in March, residents continued to ride packed subways to work, gather at nightclubs, and fill sushi bars.

The Saito-yu Public Bath and Coin Laundry kept on taking reservations for their rose baths, saké baths, candle open-air baths, and facials. Across the internet, rumours spread that hot baths and saunas killed coronavirus, even as experts warned that, with people sharing the same facilities, they could instead lead to more infections. Nevertheless, on 1 March the bath house posted a photo of hand sanitiser on its website along with the message: "Let's take measures and overcome the coronavirus together! Open as usual!"

\section{Escalation}

By 21 March, Japan had 1000 cases and 43 deaths, still few compared with outbreaks in neighbouring China and South Korea. Some experts warned that the Japanese had been living under a false sense of security ${ }^{2}$ but speculation continued. If 
Japan wasn't doing mass testing or isolation, what was the secret of its containment?

Some noted that Japanese practices of bowing instead of shaking hands or hugging, removing shoes, clean public restrooms, and the long held tradition of wearing masks in public when sick contributed to its low infection rates. Others pointed to an accessible public healthcare system and a history of strong pneumonia treatment. ${ }^{3}$

As spring arrived, groups gathered to celebrate cherry blossom festivals. In one video, maskless people gather on picnic blankets beneath the pink blossoms, sipping from plastic cups. Crowds, including elderly people, moved beneath the sakura trees, shoulder to shoulder, most wearing masks, but others not. ${ }^{4}$

By late March, the number of covid-19 cases in Tokyo began doubling daily. By 21 April, Japan had recorded over 11500 cases (712 from the Diamond Princess), around a quarter of which were in Tokyo. Experts from a government appointed panel said that the origin of infection was untraceable in as many as $40 \%$ of reported cases, with Tokyo and other prefectures saying unknown transmission accounts for $50-75 \%$ of daily cases.

\section{Healthcare on the brink}

The Japanese medical system could collapse even before a spike in infections. Such was the warning of Shigeru Omi, head of the Japan Community Healthcare Organisation, on behalf of the government panel of experts on covid-19.

Typical hospital stays of three weeks are five times longer than the three or four days normally expected for seasonal flu, and this has left a system unprepared for the sudden shortage of beds and infectious admissions. Regional hospitals, in particular, are lacking specialist wards or staff with training in how to handle patients with infectious diseases. ${ }^{5}$

According to the public broadcaster NHK, one Tokyo patient showing covid-19 symptoms was turned away by 80 hospitals. Separately, emergency department staff at the Japanese Red Cross Medical Center in Tokyo were shown calling 120 different institutions in vain, trying to find a bed for an 80 year old man with suspected coronavirus. ${ }^{6}$

On 20 April, nine prefectures reported that their hospitals were already at $80 \%$ of their capacity. The Tokyo Metropolitan Government has requested that facilities try to increase bed capacity by $50 \%$.

Until 3 April, rules required any patient testing positive for the virus to be hospitalised, no matter the severity of the symptoms. This could have overwhelmed capacity. Rules have since been relaxed to allow patients with mild symptoms to stay at home or be transferred to specially requisitioned hotels.

Toshibumi Taniguchi, an associate professor in the Department of Infectious Diseases at Chiba University Hospital, told The $B M J$ that hospitals he knew of were not yet packed with covid-19 patients, but hotels had recently been set up to take patients with mild symptoms. "There are cases in which we think the infection happened among family members," he says, "I hope this could work as effective isolation from the patient's family."

Kentaro Iwata, a professor in the Division of Infectious Disease Therapeutics at Kobe University Graduate School of Medicine, told The BMJ that medical facilities are busy, including those that do not take covid-19 patients, because they are taking care of critically ill patients who would usually be seen at other hospitals. There are not enough medical supplies and "this raises concerns among workers," he says. "Many are fearful because of unpreparedness."

"In Japan, we are short of masks, gowns, and face shields," says Taniguchi. "There are companies offering face shields made by 3D printers, so this could be a solution to our shortage."

Chiba University Hospital decided to reuse goggles by disinfecting them with alcohol wipes, Taniguchi said. "We have a shortage of N95 masks," he adds. "In our hospital, we decided to reuse them by disinfecting them with vaporised hydrogen peroxide." As for gowns, "we have no solution at the moment. Some hospitals are trying to use cheap plastic raincoats. We may have to do that as well."

\section{Reluctant testing}

Some experts believe that Japanese doctors' practice of providing tests for the virus only to very sick people with fever or other symptoms led to misleadingly low infection numbers.

Even now, not enough tests have been conducted, Koichi Nakano says, adding that the Japanese government's handling of the outbreak has been "seriously flawed." A study by the Japan Medical Association in March found that 290 requests for tests by doctors had been declined by health centres.

Safecast, an international non-profit environmental data organisation that formed after the 2011 Japan tsunami and Fukushima Daiichi Nuclear Power Plant disaster, has been gathering data throughout the covid-19 outbreak. Users have also been posting their stories of trying to get tested for coronavirus on a global Safecast tracking map. ${ }^{7}$

One 47 year old man shared his story of 23 March: "I had a fever for about five days ranging from $39.2^{\circ} \mathrm{C}$ on the high end to $37.5^{\circ} \mathrm{C}$. I also had a persistent cough," he wrote. "They asked if I had been in direct contact with someone that had travelled to China or Italy and I said no, so they said I was low risk."

The man asked for a covid-19 test. "The doctor said it was a 'difficult' test. I asked how. They said that the results didn't come back in 30 minutes, and that it was expensive." The doctors gave him a chest $\mathrm{x}$ ray and told him he did not have covid-19, "because I would have to have pneumonia to have it." He continued, "They gave me a cough suppressant and sent me home."

Many want to get tested but still cannot, says Kami. Others may also be afraid to be tested for fear of being shamed. Some who have received positive tests have been "humiliated publicly," he said. A focus on "cluster infections" around live music venues, bars, and gyms were made into public examples, and a cluster identified around a Kyoto university led to vicious attacks and discrimination against those associated with the college.

An NHK documentary, aired on 1 April, revealed the stigma faced by medical workers at Minami Seikyo Hospital in Nagoya, including family members being banned from offices, refused access to clinics, or having their children turned away from childcare or isolated in a room alone.

Public behaviour right now is inconsistent, said Nakano, who believes this is because of the government's lack of a firm stance on safety measures. In Tokyo, some buildings and streets are completely empty, he says, while in others "you cannot believe that there are so many people in mutual proximity, in shopping malls and stations."

Many in Japan do worry about the virus, he says. They don't want to get infected or infect others, so a lot of people are now staying home. But many others cannot because their companies still require them to come to work. "Japan is an orderly society, 
where people are known to behave like a polite herd," says Nakano. "It's not as if people are being reckless, defiant, or disobedient."

Competing interests: I have read and understood BMJ policy on declaration of interests and have no relevant interests to declare.

1 Looi MK. Covid-19: Japan prepares to extend state of emergency nationwide as "untraceable" cases soar. BMJ 2020:369:m1543. 10.1136/bmj.m1543 32299811 Montari S. Japan has a remarkably low number of coronavirus cases that experts worry may lead to a "false sense of security." Business Insider. 19 March 2020. www. businessinsider.com/why-japan-cases-of-coronavirus-are-so-low-2020-3.
3 Adelstein J. Japan's winning its quiet fight against covid-19. 25 March 2020. Asia Times. https://asiatimes.com/2020/03/japans-winning-its-quiet-fight-against-covid-19.

4 Japan enjoys cherry blossom despite warning over coronavirus. AFP News Agency. 22 March 2020. www.youtube.com/watch?v=y_TNuWcjF8Y

5 Covid-19 hospitals pushed to the limit. 9 April 2020. NHK World-Japan. www3.nhk.or. jp/nhkworld/en/ondemand/video/4002773.

6 Covid-19: doctors fight to save lives. 17 April 2020/ NHK World-Japan. www3.nhk.or.jp/ nhkworld/en/tv/closeup/20200418/4002779.

7 Safecast covid-19 resting map. https://covid19map.safecast.org/views/map.

Published by the BMJ Publishing Group Limited. For permission to use (where not already granted under a licence) please go to http://group.bmj.com/group/rights-licensing/ permissions 